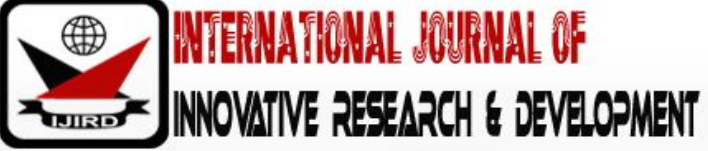

ISSN 2278 - 0211 (Online)

\section{Improving Female Students' Use of ICT Tools in a College of Education}

\begin{tabular}{|c|} 
Benjamin Baiden \\
ICT Tutor, Department of Mathematics and ICT, St. Joseph's College of Education, Ghana \\
Victor King Anyanful \\
ICT Tutor, Department of Mathematics and ICT, OLA College of Education, Ghana \\
Victor Dannyansah \\
ICT Tutor, Department of Mathematics and ICT, Atebubu College of Education, Ghana \\
Bryce Yaw Kesse \\
ICT Tutor, Department of Mathematics and ICT, Berekum College of Education, Ghana
\end{tabular}

\begin{abstract}
:
Females who are the hope of the society cannot be neglected in this digital age. One feel dejected to see level two hundred (200) female students of St. Joseph's and Berekum Colleges of Education, when they only show interest in the theory aspect of the subject (ICT), not involving themselves in the practical activities in ICT but the ICT syllabus for Colleges of Education aims at offering basic knowledge and skills to students (Ministry of Education Science and Sports, 2004). It is against this background that this research was conducted to ensure female students involve themselves and use ICT tools well in practical lessons. The researchers made use of quantitative research methodology together with random and stratified sampling techniques to collect valid data on the problem. Notwithstanding, questionnaire methodology was employed in gathering relevant data from the research population. Results from the study revealed that students reported certain things teachers do to reduce their interest in class. Teachers also reported that they deliver lessons without appropriate TLMs. Based on the findings, it was recommended that students should be given career guidance and counselling on the relevance of the subject through career conferences and conventions. In doing this, role models should be used. It was also recommended that school authorities must ensure provision of adequate ICT tools to facilitate the teaching and learning of ICT. They should also adopt monitoring system on teachers' effective use of the equipment.
\end{abstract}

Keywords: College of education, information and communication technology, female education, motivation, ICT tools

\section{Introduction}

The impact of ICT on learning is currently in relation to the use of digital media, primarily computers and internet to facilitate teaching and learning. ICTs are the technologies used in conveying, manipulation and storage of data by electronic means; they provide an array of powerful tools that may help in transforming the present isolated teachercentered and text-bound classrooms into rich, student-focused, interactive knowledge environments.

To meet these challenges, learning institutions must embrace the new technologies and appropriate ICT tools for learning. The direct link between ICT use and students' study habit and academic performance has been the focus of extensive literature during the last two decades. Some of them help students with their learning by improving the communication between them and the instructors (Valasidou \& Bousiou, 2005).

Leuven (2004) stated that there is no evidence for a relationship between increased educational use of ICT and students' performance. In fact, they found a consistently negative and marginally significant relationship between ICT use and some student achievement measures. For instance, some students may use ICT to increase their leisure time and have less time to study. Online gaming and increased communication channels do not necessarily means increased achievement.

On the other hand, Abdulla and Twizell (2008), state that ICT has the potential to transform the nature of education; where and how learning takes place and the roles of students and teachers in the learning process. Karim and Hassan (2006) noted the exponential growth in digital information, which changes the way students perceive study and reading and in how printed materials are used to facilitate study.

Based on the extended usage of ICTs in education, the need appears to unravel the myth that surrounds the use of information and communication technology (ICT) as an aid to teaching and learning, and the impact it has on students' study habits and academic performance.

\subsection{Research Question}

The research question used for this study is as follows: 
- What can teachers do to develop female students' interest in practical activities?

\subsection{Reviewed Materials and Methods}

The theories examined and discussed under this study include the following:

Need theory (Maslow, 1954), Two-factor theory (Herzberg, 1964), Self-determination theory (Deci \& Ryan, 1985) and Existence, related and growth theory (Alderfer, 1977).

\subsection{Need Theories}

Analysis of Abraham Maslow's theory of need hierarchy which seems to be the fundamental motivational theory is as follows:

\subsubsection{Physiological Needs}

These are biological needs. They consist of needs for oxygen, food, water, and a relatively constant body temperature. They are the strongest needs because if a person were deprived of all needs, the physiological ones would come first in the person's search for satisfaction.

\subsubsection{Safety Needs}

When all physiological needs are satisfied and are no longer controlling thoughts and behaviours, the needs for security can become active.

Children often display the signs of insecurity and the need to be safe.

\subsubsection{Needs of Love, Affection and Belongingness}

Maslow states that people seek to overcome feelings of loneliness and alienation. This involves both giving and receiving love, affection and the sense of belonging.

\subsubsection{Needs for Esteem}

These involve needs for both self-esteem and for the esteem a person gets from others. Humans have a need for a stable, firmly based, high level of

Self-respect, and respect from others. When these needs are frustrated, the person feels inferior, weak, helpless and worthless.

\subsubsection{Needs for Self-Actualization}

'When all of the foregoing needs are satisfied, then and only then are the needs for self-actualization activated. Maslow describes self-actualization as a person's need to be and do that which the person was "born to do." "A musician must make music, an artist must paint, and a poet must write."

These needs make themselves felt in signs of restlessness.

Simons (1987) accepted the fact that this theory has influenced a number of different fields, including education. This wide influence is due in part to the high level of practicality of Maslow's theory. It is therefore undeniable fact that these needs must be considered in every aspect of life. Teachers and stakeholders in education should accept that these needs are interwoven; one must be satisfied before the other.

Neglecting one will definitely affect the next level of need. Classroom instruction must take these into consideration in order to ensure psychological, emotional and physical readiness of learners.

\subsubsection{Empirical Basis of the Study}

Empirical basis of a research work can be defined as "research based on experimentation or observation. The word empirical means information gained by experience, observation, or experiment. The central theme in scientific method is that all evidence must be empirical which means it is based on evidence. In scientific method the word "empirical" refers to the use of working hypothesis that can be tested using observation and experiment. Empirical basis or evidence is information that justifies a belief in the truth or falsity of an empirical claim. In the empiricist view, one can only claim to have knowledge when one has a true belief based on empirical evidence

In addition, an empirical basis of a research work is a way of gaining knowledge by means of direct and indirect observation or experience. Empirical evidence (the record of one's direct observations or experiences) can be analyzed quantitatively or qualitatively. Through quantifying the evidence or making sense of it in qualitative form, a researcher can answer empirical questions, which should be clearly defined and answerable with the evidence collected (usually called data). Research design varies by field and by the question being investigated. Many researchers combine qualitative and quantitative forms of analysis to better answer questions which cannot be studied in laboratory settings, particularly in the social sciences and in education.

Uniquely, empirical basis of a research work has important objectives as follows:

- Goes beyond simply reporting observations.

- Promotes environment for improved understanding.

- Combines extensive research with detailed case study.

- Proves relevancy of theory by working in a real-world environment (context).

Arguably, some of the reasons by which empirical research methods can be used are as follows:

- Traditional or superstitious knowledge has been trusted for too long. 
- Empirical Research methods help integrating research and practice.

- Educational process or Instructional science needs to progress.

Moreover, the use of empirical basis or support in a research work/ study has the following advantages.

- Understands and responds more appropriately to dynamics of situations.

- Provides respect to contextual differences.

- Helps to build upon what is already known.

- Provides opportunity to meet standards of professional research.

In effect, the collection of evidence to prove or counter any theory involves planned research designs in order to collect empirical data. Several types of designs have been suggested and used by researchers. Also, accurate analysis of data using standard statistical methods remains critical in order to determine legitimacy of empirical research.

Literature review on previous studies or research related to this study have been discussed under the following headings; employing motivation to sustain female students' participation in practical lessons of ICT and exploration of factors that motivate female students in acquiring practical skills.

\section{Methodology}

\subsection{Introduction}

This action research aimed at employing strategies to ensure female students' involvement and use of ICT tools in ICT practical/ activity lessons in St. Joseph's and Berekum Colleges of Education in the Brong Ahafo. Accordingly, Leedy (1993) stated that a method is a way of accomplishing an end result. A research methodology, therefore, refers to a set of methods, systems and procedures used in a particular research to achieve stated objectives. Additionally, the word method is coined from two Greek words: 'meth' and 'odos'. A method is therefore, following after the way someone found to be effective in solving a problem or reaching an objective or getting a job done. The meth means 'after' and 'odos' means 'way'. Thus, if the data is verbal, the methodology is qualitative; if the data is numerical, the methodology is quantitative hence this study employed a quantitative methodology.

\subsection{Research Design}

According to Grandhi (2004), "a research design is the tentative outline of a proposed research work". Kerlinger (1986) defines research design as "a plan structure and strategy of investigation so convinced as to obtain answers to research questions or problems". Similarly, a research design is a procedural plan that is adopted by a researcher to answer questions in a valid way, as a provisional outline of this action research, the researchers employed about six (6) strategies to determine the appropriate research design.

The action research/case study is mainly descriptive since it involves investigating, recording, analyzing and interpreting data. According to Gerber (2009), "the aim of descriptive research is to verify formulated hypotheses that refer to the present situation in order to elucidate it". This method seeks to describe the phenomenal change that will be manifested when female students are motivated and encouraged to fully participate and use ICT tools in ICT.

\subsection{Research Population}

A research population is a group of individuals, persons, objects, or items from which samples are taken for measurement (Mugo, 2009). In this regard, the present researchers considered the teaching and learning situation in the schools which called for two categories of people who were directly involved. Students and teachers of St. Joseph's and Berekum Colleges of Education were therefore captured as the main population for the study. The choice of this population became necessary since it was hoped to provide the researchers with relevant and immediate data needed for the analysis.

\subsection{Sample and Sampling Procedure}

According to Grandhi (2004) "a complete coverage of the units of the universe selected for research, is not possible. Instead of complete coverage, selected units are studied". Lunsford and Lunsford (1995, p55), also defined sample as "a small subset of the population that has been chosen to be studied". Lunsford and Lunsford further cautioned that "the sample should represent the population and have sufficient size ....". Best and Kahn (1989) have observed that the primary aim of research is to discover principles that have universal application.

In this regard, the researchers saw that considering the entire population would not help; instead part of the population would be sampled to ensure reliability and validity of data collection. The sample for the study was made up of one hundred and twenty (120) female students who were in the said Colleges of Education level two hundred (200), and forty (40) teachers.

The simple random sampling method was used to select the sample. The said sample is probability in nature in which each member of the population had a known and equal chance of being chosen in the sample. The method helped the researchers to identify and enumerate the finite population. To avoid selection bias, it is important to guarantee that each of the candidates for inclusion in the study has an equal opportunity for selection (Lunsford \& Lunsford, 1995).

Stratified sampling technique was also adopted alongside the random sampling since the study concerned the inclusion of gender group (female students) in ICT. According to Lunsford and Lunsford (1995), stratified sampling is "a method by which subjects are grouped according to strata such as age, gender or diagnosis. Using this method, subgroups of interest could be defined and ... sampled for each group". 
The said subgroup included seventy five percent (75\%) female students and twenty five percent (25\%) teachers who were used for the study.

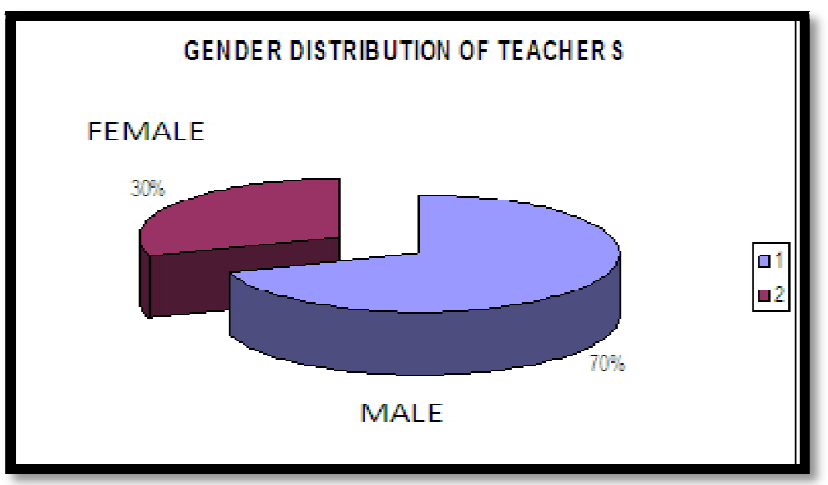

Figure 1: Gender Distribution of Teachers

\subsection{Instrumentation}

Research techniques refer to the methods for gathering reliable information to answer a question or support an experimental hypothesis (Okai, 2009). In view of this, the researchers of this study employed questionnaire technique to gather valid and reliable data in aid of rectifying the situation at hand. It must be emphasized here that good data is directly related to the questions; that is, they provide direct answers (Padak \& Padak, 2009).

According to Cohen, Manion and Morrison (2003), questionnaires can provide a structured and straightforward analysis of information. Moreover, questionnaires are relatively more economical than other approaches in terms of time and money and they can be convenient for respondents as they can complete them in their own time.

Questionnaire is usually more superficial than the interview. It is usually used in group work. The questionnaire is especially useful to obtain information about reasonably big groups. Questionnaire is usually characterized by relatively low cost, ease of interpreting information, and likelihood of answering each question.

\subsection{Data Collection Procedure}

The present researchers therefore sat down to carefully plan, design and administer one hundred and sixty (160) questionnaires to respondents (female students and teachers) to obtain information on the topic under discussion. These questionnaires were presented to the respondents during the data collection stage of the study. The items in the questionnaires were written in clear language to enable respondents understand and answer the questions objectively as possible. The choice of the questionnaire technique for the study was that many respondents could be reached within a short period of time. Respondents were expected to answer every item in the questionnaire. It also required little time of respondents. Some examples of sample items on the questionnaire included 'I am regular at ICT practical lessons', 'I feel happy and satisfied in ICT classes, 'Practice makes man perfect', etc.

In addition, the respondents were given little opportunity to express their views as they were restricted to the questions and their corresponding answers. The main items contained in the questionnaire included how motivation can add value to female students' participation in ICT practical lessons; what teachers can do to develop female students' interest in ICT lessons and finally relationship between practical learning and students' performance.

\subsection{Intervention Design and Implementation}

This aspect of the study presents the actual measures were taken to alleviate the problem understudy. To intervene means "to become involved, intentionally, in a difficult situation in order to improve it or prevent it from getting worse". The researchers, after considering existing literature on the problem, came out with six (6) interventional strategies and their implementation which contributed to overcoming the challenges.

\subsection{Intervention Design}

Classroom research/ Case study focuses on identifying or evaluating the "method in our madness" as it affects our students' learning.

As classroom teacher who has been teaching ICT at St. Joseph's College of Education since 2009 academic year, and attending certain academic programs in Berekum College of Education as well, a number of challenges that affect female students' learning and academic performance have been observed. The involvement and improvement in the use of technological equipment (ICT tools) among female students has become unease. The researchers of this study observed similar situation even among his university female counterparts during the period of study at the university.

Encouraging females' participation and improvement in practical lessons in ICT through motivation and attractive techniques was hoped to alleviate the fear and nervousness and equip them with the skills of using modern technology. To do this, the researchers proposed the following interventional designs and mechanisms to effect a change in female students' attitude towards practical lessons in ICT.

- Motivational techniques

- Good teacher-student relationship

- A talk on career opportunities in ICT 
- Applying a variety of teaching methods

- Provision of guidance and counseling

- Maintaining good attitude of students and teachers towards ICT

\section{Data Analysis and Results}

This chapter focuses on the presentation and analysis of data gathered from the field.

Students were asked whether they are regular at ICT practical lessons. They were to choose one of the following options: 'very true of me', 'true of me' and' 'not true of me'. Table 1 shows that 76 (i.e.63.3\%) chose very true of me, 41 (i.e. 34.2\%) chose true of me and finally 3 (i.e. $2.5 \%$ ) chose not true of me.

This means that students' regularity at ICT practical lessons has seen tremendous improvement. The significance of this finding is that students believed if they feel secured, respected, esteemed, and empowered, they are likely to make a strong effort in ICT in practical lessons.

\begin{tabular}{|c|c|c|}
\hline Responses & Frequency & Percentage \\
\hline Very true of $m e$ & 76 & 63.3 \\
True of me & 41 & 34.2 \\
Not true of me & 3 & 2.5 \\
\hline Total & 120 & 100.0 \\
\hline
\end{tabular}

Table 1: Students' Regularity at ICT Practical Lessons

Source: Field Work July, 2018 (SPSS V16.0)

Table 2 shows students' responses when they were asked to indicate whether they are very active, active, and dormant, to the statement students' attitudinal level during ICT practical lessons. 46 (i.e. 38.3\%) of them indicated that they are very active while 63 (i.e. 52.2\%) of them indicated that they are active. However, 11 (i.e. 9.2\%) of them indicated they are dormant.

It can be deduced from the table that students' attitudinal level in ICT practical lessons has soon a major improvement. The relevance of this finding shows that motivation had increased the likelihood that students would pay attention to something, study and practice it, and try to learn in a meaningful fashion.

\begin{tabular}{|c|c|c|}
\hline Responses & Frequency & Percentage \\
\hline Very active & 46 & 38.3 \\
Active & 63 & 52.2 \\
Dormant & 11 & 9.2 \\
\hline Total & 120 & 100.0 \\
\hline
\end{tabular}

Table 2: Students' Attitudinal Level in ICT Practical Lessons

Source: Field Work July, 2018 (SPSS V16.0)

Table 3. shows responses of teachers when they were asked whether they are regular at handling all lessons. 30 (i.e. $75 \%$ ) of them indicated very true of me and 10 (i.e. $25 \%$ ) of them indicated true of me.

It is clear from the table that teachers' regularity at handling lessons has improved. The relevance of this finding shows that students believed teachers' consistent regularity at lessons ginger them to be regular at all lessons as well.

\begin{tabular}{|c|c|c|}
\hline Responses & Frequency & Percentage \\
\hline Very true of me & 30 & 75.0 \\
True of me & 10 & 25.0 \\
\hline Total & 40 & 100.0 \\
\hline
\end{tabular}

Table 3: Teachers' Regularity at Handling Lessons

Source: Field Work July, 2018 (SPSS V16.0)

When asked about the punctuality of teachers to class, 26 (i.e. 65\%) of the respondents indicated some minutes before time while 14(i.e. 35\%) of them indicated exactly time.

As reflected in table 4.3.2, it is undoubtedly clear that teachers are punctual to class. The significance of this finding also shows students appreciated the fact that teachers' punctuality to class has affected them positively in their learning.

\begin{tabular}{|c|c|c|}
\hline Responses & Frequency & Percentage \\
\hline Some minutes before time & 26 & 65.0 \\
Exactly time & 14 & 35.0 \\
\hline Total & 40 & 100.0 \\
\hline
\end{tabular}

Table 4: Teachers' Punctuality to Class

Source: Field Work July, 2018 (SPSS V16.0)

\section{Conclusion}

Improving female students' use of ICT tools is progressively more attracting research; nevertheless, this research is chiefly conducted in or by developed countries with a slight share of research emerging from developing countries. Very 
little work has been done by Ghanaians regarding female students' use of ICT tools in our educational system. It is in this light that this research is undertaken to look at how female students' use of ICT tools can be of paramount priority in the Ghanaian educational system.

The researchers could not undertake the study in the entire country but restricted himself to the Colleges of Education in the Brong Ahafo region and chose only two colleges involving a few respondents in order to obtain a very consistent data to address the identified problem.

The said colleges were selected at random from one (1) Municipal area and one (1) District in the Brong Ahafo region of Ghana for the research. The Municipal area was Berekum and the District was Bechem (Tano South). In each of the colleges, the following were given questionnaires to respond to:

- $\quad$ Female students.

- Teachers.

A total of one hundred and sixty (160) respondents were selected for the research. Random sampling and stratified sampling methods were used to select the colleges and the students for the research. The type of tool used to gather data for this research was questionnaire. The researchers personally administered questionnaires directly to the respondents in their colleges after obtaining permission from the Heads. The administration of the questionnaires was done with the help of the teachers of the colleges chosen for the study. Here, the researchers explained to the students the purpose of the study and how to fill the questionnaires. With the help of the teachers, 120 female students (i.e. 60 from each college) from level two hundred were selected at random to respond to the questionnaires. The questionnaires were collected immediately after the students had finished responding to them. Having finished with the students, 40 teachers (i.e. 20 from each college) were also given their questionnaires to complete on the same day.

\section{References}

i. Allen, D. (ed) (1974). Instruction. In Malvin L. B. The Philosophy for Quality Vocational Education Programs. Washington, DC: American Vocational Association

ii. Adentwi, K.I. (2009). Psychology of Human Development. Kumasi: Biraa Press. pp. 22-40

iii. Archer, F. (2003). Measurement and evaluation in education. Kumasi: PAKS Publications, pp. 13

iv. Asiedu-Addo, S. (2008). Encourage females to study technical subjects. Junior Graphic. pp. 3.

v. Assoah, S. K. (2008). Guidance \& counseling in education. Kumasi: Biraa Press. pp. 10

vi. Abdulla, Y. \& Twizell, EH. (2008). Higher Education in the 21st Century: Issues and Challenges. London, Taylor \& Francis Group, UK.

vii. Bacon, F. (2008). Set it down to thyself, as well to create good precedents as to follow them. In Microsoft Encarta Student 2009 [DVD]. Washington Redmond: Microsoft Corporation

viii. Becta (2008). How do boys and girls differ in their use of ICT? - Research report Retrieved July 18 2018, from http:/ / partners.becta.org.uk/ uploaddir/

ix. Ben-Jacob, M. G. (2005). Integrating computer ethics across the curriculum: A case study, Educational Technology \& Society, pp. 198-204.

x. Berliner, D. C. (2008). Educational psychology. In Microsoft Encarta Student 2009 [DVD]. Redmond, WA: Microsoft Corporation.

xi. Brause, R. S. \& Mayher, J. S. (Ed.) (1994). Search and re-search: what the inquiring teacher needs to know. United Kingdom: The Falmer Press, Rankine Road Basingstoke, Hampshire RG24 OPR87

xii. Broussard, S. C., \& Garrison, M. E. B. (2004). The relationship between classroom motivation and academic achievement in elementary school-aged children. Family and Consumer Sciences Research Journal, 33(2), 106120.

xiii. Brickman, W. W. (2008). Vocational education. In Microsoft Student 2009 [DVD]. Redmond, WA: Microsoft Corporation.

xiv. Brundtland, G. H. (2002). World Health Organization (WHO) Director-general's executive statement on gender policy: Integrating Gender Perspectives ithe Work of WHO.

xv. Clark, R.C \& Mayer, R.E. (2003). E-Learning and the science of Instruction: proven guidelines for consumers and designer's multimedia learning. SanFrancisco: Pfeiffer

xvi. Cradler, J., McNabb, M., Freeman, M. \& Burchett, R. (2002). How does technology influence student learning. Retrieved March 15, 2018, available at: http:/ / caret.iste.org/ caretadmin/ news documents/ StudentLearning.pdf.

xvii. Conner, M. L. (2007). A primer on educational psychology. Retrieved February 18, 2009, available at: http:// agelesslearner.com

xviii. Deci, E. L. \& Ryan, R. M. (1985). Intrinsic motivation and self-determination inhuman behavior. New York: Plenum. ISBN 0-30-642022-8.

xix. Derbyshire, H. (2003). Gender issues in the use of computers in education in Africa,DFID: 73

xx. Deci, E. L. (1971). Effects of externally mediated rewards on intrinsic motivation. Journal of Personality and Social Psychology, 18, 105-115.

xxi. Eisenberg, N. (2010). Self-regulation and school readiness. Early Education and Development, 21(5), 681-698.

xxii. Eccles, J., Midgley, C., and Wigfield, A., (1993). Development during adolescence: The impact of stageenvironment fit on young adolescents' experiences in schools and families. American Psychologist, 48, 90-101.

xxiii. Eisenberger, R., \& Cameron, J. (1996). Detrimental effects of reward: Reality or myth? American Psychologist, 51, 1153-1166. 
xxiv. Entwistle, N. J (general editor) (1990). Handbook of educational ideas and practices. London and New York: Routledge pp. 144.88

xxv. Fuglestad, A. B. (2005). Students' use of ict tools - choices and reasons. In Chick, H.L.\& Vincent, J. L. (eds.) Proceedings of the 29th conference of the international group for the psychology of mathematics education. Melbourne: PME, Agder University College Vol. 3, pp. 1-8.

xxvi. Guay, F. (2010). Intrinsic, identified, and controlled types of motivation for school subjects in young elementary school children. British Journal of

xxvii. Educational Psychology, 80(4), 711-735.

xxviii. Gerber, R. (2009). Research skills: Centre for Teaching, Learning and Media. Nelson

xxix. Mandela Metropolitan University. Retrieved March 15, 2018 from

xxx. http:/ / www.petech.ac.za/ robert/ research.html

xxxi. Grandhi, N. (2004). Introduction to research methodology, Block 1. National Open

xxxii. University, School of Social Sciences.

xxxiii. Grubb, W.N., Lazerson, M. (2005). Vocationalism in Higher Education: The Triumph of the Education Gospel.

xxxiv. Garrison, D.R \& Anderson, T. (2003). E-learning in the 21sth century - A framework for research and practice. New York and London, Routledgefalmer.

xxxv. Greer, L. (2001). Does changing of Method of Assessment of a Module Improve the

xxxvi. Performance of a Student. Assessment and Evaluation in Higher Education.

xxxvii. 26(2)

xxxviii. Hafkin, N. \& Taggart, N. (2001). Gender, information technology, and developing countries: An Analytic Study. Washington: USAID Retrieved April

xxxix. 17, 2009 from http:/ / www.usaid.gov/ wid/ pubs/it01.htm

xl. Hyde, J. S., \& Kling, K. C. (2001). Women, motivation, and achievement. In

xli. Psychology of Women Quarterly, 25, pp. 364-378

xlii. Haynie, W. J. III (2003) Gender issues in technology education: A Quasi- Ethnographic Interview Approach. In Journal of Technology Education

xliii. Vol. 15 No. 1, Fall2003

xliv. Hornung-Prahauserm, R. M. V, Eliane S. (2005). Inclusion of females in ICT - A lifelong learning challenge for change agents: Benefits of innovative e-learning tools and training methods. Retrieved March 10, 2018, fromhttp:/ / www.salzburgresearch.at/ research gfx/ eden proict 2005.pdf

xlv. Harter, S. (1981). A new self-report scale of intrinsic versus extrinsic orientation in the classroom: Motivational and informational components. Developmental Psychology, 17, 300-312.

xlvi. Harter, S. (1992). The relationship between perceived competence, affect, and motivational orientation within the classroom: Processes and patterns of change. In A. K.

xlvii. Johnson, K. (2003). Telecentres and the gender dimension: an examination of how engendered telecentres are diffused in Africa. Georgetown: Unpublished MSc thesis, Georgetown University.

xlviii. KNUST (2009). Admission brochures for 2009/2010 academic year. Kumasi: Kwame Nkrumah University of Science and Technology. Retrieved February 07, 2009, from http:/ / admissions.knust.edu.gh

xlix. Leedy, P. D. (1985). Practical research: planning and design. (3rd ed.). New York: McMillan Publishing Co.

1. Lunsford, T. R. \& Lunsford, B. R. (1995). Research forum--the research sample, part I: sampling, In Journal of Orthotists and Prosthetists, America Academy of

li. Orthotists and Prosthetists. Retrieved May 13, 2018, from http:/ / www.oandp.org/jpo/ library/ index/ 1995 03.asp. pp. 105-112

lii. Leuven, Z. (2004). Reading Behaviour in the digital environment: changes in

liii. Reading behaviour over the last 10 years. J. Doc, 61 (6): 700-12

liv. Macueve, G., Mandlate, J., Ginger, L., Gaster, P. \& Macome, E. (2009). Women's use of information and communication technologies in Mozambique: a tool for empowerment? pp. 22

lv. Martin, A. \& Marsh, H. (2005). Motivation of girls' research article. In Australian

lvi. Journal of Education (2009) Motivating boys and motivating girls: does teacher gender really make a difference? .

lvii. Maslow, A. H. (1943). A theory of human motivation. Psychological Review, 50, pp. 370-396

lviii. Millar, J. \& Jagger, N. (2001). Women in ITEC Courses and Careers. Brighton, UK: University of Sussex. pp. 40-50. Retrieved March 10, 2018, from http:// www.womenandequalityunit.gov.uk/ research/pubn_2001.html

lix. Mitter, S. (2007). Globalisation and ICT: Employment Opportunities for Women Part III.

lx. Mugo, F. W. (2009). Sampling in research. London: Chapman \& Hall. pp. 169-184.

lxi. Maslow, A. (1954). Motivation and personality. New York: Harper.

lxii. Margolis, J. \& Fisher, A. (2002). Unlocking the clubhouse: Women in ComputingMT Press

lxiii. Nobel, C. (2007). Back to school: getting girls into IT. In InfoWorld. 29 January, Retrieved March 10, 2018, from www.infoworld.com/article/ 07/ 01/ 29/ 05FEwomentechteen 1.html

lxiv. Nulden, U. (1998). The Excon Project: Advocating Continuous Examination. The

lxv. SIGSCE Technical symposium on Computer Science Education, Atlanta,

lxvi. USA, ACM Press

lxvii. Needham, R \& Hill, P. (1987). Teaching strategies for developing understanding inscience; Children's Learning in Science Project. Leeds: University of Leeds, LS2 9JT. 
lxviii. OECD/ European Communities (2004). Career guidance: a handbook for policymakers. France Paris: OECD Publications, 2. Retrieved March 25, 2018 from http:/ / www.oecd.org/ dataoecd/ 53/ 53/ 34 060761.pdf

lxix. Omamo, S. A. (2009). Reflections on the mentoring experiences of ICT career women in Nairobi, Kenya: looking in the mirror. In The International Development Research Centre (IDRC). pp. 19 of 22

lxx. Owusu-Banahene, N. O. (2007). Educational psychology: The science of learning. Kumasi: Narco Printing Works, KNUST, pp. 222-231.

lxxi. Padak, N. \& Padak, G. (2009). Research to practice: guidelines for planning action research projects. In Ohio Literacy Resource Center. Retrieved 15, 2009, from http:/ / literacy.kent.edu/ Oasis/ Pubs/ 0200-08.htm

lxxii. Pamela J. S. \& Stephenson, R. (2008). Giving and getting career advice: a guide for junior and senior faculty. Retrieved March 29, 2018, from http:/ / sitemaker.umich.edu / advance

lxxiii. Passey, D. (2004). The motivational effect of ICT on pupils - research report RR523. DfES. In Becta (2008) How do boys and girls differ in their use of ICT? Retrieved July 18, 2018, from http:/ / partners.becta.org.uk/ uploaddir/ downloads / page_documents/ research/gender_ict briefing.pdf

lxxiv. Payton, F., L. Kvasny, V. M. \& Amadi, A. (2007). Gendered perspectives on the digital divide IT education and workforce. Proceedings of the 9thInternational Conference on Social Implications of Computers inDeveloping Countries, São Paulo.

lxxv. Pintrich, P. R., \& Schunk, D. (2002). Motivation in education: Theory, research and applications (2nd ed.). Upper Saddle River, NJ: Prentice-Hall.

lxxvi. Robin, A. (1997). Policy and practice in primary education local initiative: NationalAgenda (2nd ed). London: Routledge, EC4P 4EE 11 New Fetter Lane.

lxxvii. Ryan, R. M., \& Deci, E. L. (2000). Self-determination theory and the facilitation intrinsic motivation, social development, and well-being. American Psychologist, 55, 68-78.

lxxviii. Rogers, C. (1963). The actualizing tendency in relation to "motives" and toconsciousness. In M. R. Jones (Ed.), Nebraska symposium on motivation (Vol11, pp. 1-24). Lincoln, NE: University of Nebraska Press.

lxxix. Skinner, B. F. (1953). Science and human behavior. New York: Macmillan.

lxxx. Samman, T. (2008). Promoting ICT among young women in Europe. In Microsoft Corporate Affairs. Retrieved March 29, 2018, fromhttp:/ / www.buildaskill.com/ blog/ category/ editorials/ commentary

lxxxi. Sarfo, F. K. (2007). Educational technology; instructional technology. Kumasi: Ospra Publishing Company Limited, pp. 118, 128.

lxxxii. Sarfo, F.K. (2009). Practice (learning method).Kumasi: Ospra Publishing Company Limited, pp. 130, 152.

lxxxiii. Shackelford, R. (2006). Computing curricula 2005: The overview report, the

lxxxiv. association for computing machinery (ACM), the association for

lxxxv. information systems (AIS), the computer society (IEEE-CS).Retrieved March

lxxxvi. 25, 2018 from http:/ / www.acm.org/ education/ curric_vols/ CC2005-

lxxxvii. March06Final.pdf

lxxxviii. Sharma, U. (2003). Women's empowerment through information technology, New

lxxxix. Delhi: Authors' Press.92

xc. Shin, H. K. (2004, October 1). Using technology to guide the learning of declarative knowledge. In ITE teachers' conference: Reflective practitioners in action. Singapore: institute of technical education

xci. Simons, J. A., Irwin, D. B. \& Drinnien, B. A. (1987). Psychology - the search for understanding. New York: West Publishing Company. Retrieved February18, 2009,

frhttp:/ / honolulu.hawaii.edu/ intranet/ committees/ FacDevCom/ guidebk/ teachtip/ maslow.htm

xcii. Stephen, A. (2006). Communication technologies and women's empowerment. New Delhi: Rajat.

xciii. Ghana. Ministry of Education Science and Sports (2004). Teaching syllabus for information and communications technology (College of Education).Accra: Ministry of Education Science and Sports, pp. ii

xciv. Van Lier, L. (1996). Interaction in the language curriculum: awareness, autonomy and authenticity. London: Longman.

xcv. Ghana. WAEC (2008). Online registration, West African Examination Council. Retrieved March 29, 2018, from http:/ / www.waecdirect.org

xcvi. Weller, M. (2005). General principles of motivation. In Los Angeles Business Journal.

xcvii. White, R. W. (1959). Motivation reconsidered: The concept of competence. Psychological Review, 66, 297-333.

xcviii. Zimmermann, L. \& Sprung, G. (n.d.) Technology is female: How girls can be motivated to learn programming and take up technical studies through adaptations of the curriculum, changes in didactics, and optimize interface design. Graz, AUSTRIA: Alte Poststr. 149, 8020. Retrieved July18, 2018, from http:/ / icee2008hungary.net/ download/ fullp/ full_papers/ full_paper454.pdf 